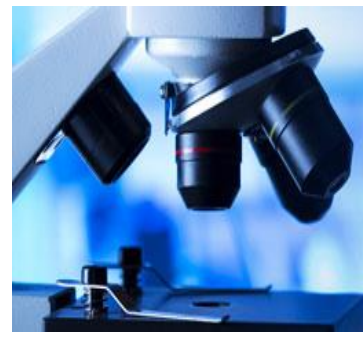

E-ISSN: 2707-4455 P-ISSN: 2707-4447 IJFM 2020; 2(1): 16-20

Received: 15-11-2019

Accepted: 18-12-2019

Dr. Priyanka Anant Patil Assistant Professor,

Department of Forensic

Medicine and Toxicology, Government Medical College, Nagpur, Maharashtra, India

Corresponding Author: Dr. Priyanka Anant Pati Assistant Professor, Department of Forensic Medicine and Toxicology, Government Medical College, Nagpur, Maharashtra, India

\section{Medico-legal autopsy study of alleged dowry deaths - A two year study}

\section{Dr. Priyanka Anant Patil}

DOI: $\underline{\text { https://doi.org/10.33545/27074447.2020.v2.i1a.20 }}$

\begin{abstract}
Background: In India, dowry is a rising social evil contributing to female mortality.

Material and Methods: Observational, prospective study of 84 alleged dowry deaths stratifying the socio-demographic pattern of alleged dowry deaths.

Results: $57.1 \%$ were from 21to30 years of age group. Maximum females were illiterate (39.3\%), housewives $(77.4 \%)$ and from lower socio-economic strata of society (56\%). In $70.2 \%$ cases, deaths occurred in own or in-law's residence. $36.36 \%$ burn victims were brought dead with $50 \%$ cases involving $71-90 \%$ of total body surface area. $29.8 \%$ were hospitalised. In $88.57 \%$ of suicidal cases, menstruation was noted $39.29 \%$ deaths were within 1 st year of marriage. In $84.84 \%$ cases, dowry was provocating factor. In $50 \%$ cases Asphyxia was the cause of death.
\end{abstract}

Conclusion: Domestic abuse and dowry were significant provocative factors for dowry deaths.

Keywords: alleged dowry deaths, suicides, menstruation, asphyxia

\section{Introduction}

"Women are the architects of the society", Harriet Beecher Stowe, American Author quoted. Though females are important pillars of our society they are given secondary roles. Women have limited power in decision making of household. They are often discriminated against in education. In India, women also fall victims against violent crimes at high rates. Different age groups of females succumb to different social crimes ${ }^{[1]}$.

Dowry is a symbol of love from parents to their daughters on the eve of her marriage. The purpose of this practice was probably meant to help new couples start their life in comfort. But it has, in recent years, grown into a social evil with many instances of bride-burning and suicides. These are symptoms of social corruption ${ }^{[2]}$.

Dowry is one of the important factors amongst all other factors responsible for crime / unnatural deaths of females in India. According to National Crime Record bureau of India total dowry death in the year 2007 and 2011 were 8093, 8618 respectively ${ }^{[3]}$.

This study enlightens the issue of dowry deaths in a metropolitan city of Maharashtra. It stratifies the gravity of this problem and allows to analyse the various possible sociodemographic and medico-legal aspects of alleged dowry deaths.

\section{Material and methods}

This is a study of observational, prospective study design with a study period of 2 years i.e. from 1st October, 2016 to 30th September, 2018 conducted at the Department of Forensic Medicine and Toxicology, in a tertiary care centre in a metropolitan city. This study has been approved by the Ethics Committee. Reference population included cases reported and referred to this study centre, while study population included Unnatural female deaths within 7 years of marriage with the allegation of dowry death. 241 unnatural female deaths are examined in the study period, of which in 84 cases allegation of dowry death is observed. Various relevant socio-demographic and medico-legal aspects are stratified and analysed with the resource being Postmortem examination reports, documents of investigating agencies like police inquest Panchnama, Magistrate inquest Panchnama wherever applicable, Accidental Death Report and statements of relatives taken by police during investigation, Spot Panchnama, suicide notes if applicable. All findings are explained and portrayed in tabular form and inference is extracted. After entry, data is analysed using frequency distribution and statistical test with the help of computer generated software (S.P.S.S.16.0). 


\section{Results}

Out of 241 Unnatural female deaths observed in the present study centre, 84 alleged dowry deaths are analysed.

Table - 1 depicts age group distribution among alleged dowry deaths. Maximum alleged female dowry victims (57.1\%) belonged to the age group of 21 to 30 years of age and minimum $(7.1 \%)$ belonged to the age group of 41 to 50 years of age.

Table 1: Age group distribution among alleged dowry deaths

\begin{tabular}{|c|c|c|}
\hline Age group (years) & Frequency & Percentage \\
\hline 11 to 20 & 11 & 13.1 \\
\hline 21 to 30 & 48 & 57.1 \\
\hline 31 to 40 & 19 & 22.6 \\
\hline 41 to 50 & 6 & 7.1 \\
\hline Total & 84 & 100.0 \\
\hline
\end{tabular}

Table no 2 describes occupational status of alleged dowry deaths. Maximum number of female victims of alleged dowry are housewives $(77.4 \%)$ and minimum number of professionals $(2.4 \%)$ with 1 victim who was working as house help.

Table 2: Occupational status among alleged dowry deaths

\begin{tabular}{|c|c|c|}
\hline Occupation & Frequency & Percentage \\
\hline Professional & 2 & 2.4 \\
\hline Clerical & 3 & 3.6 \\
\hline House help & 1 & 1.2 \\
\hline Housewife & 65 & 77.4 \\
\hline Laborer & 10 & 11.9 \\
\hline Tailor & 3 & 3.6 \\
\hline Total & 84 & 100.0 \\
\hline
\end{tabular}

Table no 3 shows distribution of educational status among alleged dowry victims. Maximum female victims are illiterate $(39.3 \%)$. Only $(3.6 \%)$ female victims are Professionals and $(2.4 \%)$ received intermediate school education.

Table 3: Educational status among alleged dowry victims

\begin{tabular}{|c|c|c|}
\hline Educational status & Frequency & Percentage \\
\hline Illiterate & 35 & 39.3 \\
\hline Primary & 7 & 8.3 \\
\hline Middle & 26 & 31.0 \\
\hline High school & 6 & 9.5 \\
\hline Intermediate & 2 & 2.4 \\
\hline Graduate & 5 & 6.0 \\
\hline Professional degree & 3 & 3.6 \\
\hline Total & 84 & 100.0 \\
\hline
\end{tabular}

Table No 4 describes socioeconomic status of alleged dowry victims according to Kuppuswamy's classification. Maximum female victims of alleged dowry death belonged to upper lower socioeconomic class $(56 \%)$ and minimum belonged to upper socio-economic class $(21.4 \%)$.

Table 4: Socio-economic status among alleged dowry deaths

\begin{tabular}{|c|c|c|}
\hline Socioeconomic status & Frequency & Percentage \\
\hline Upper (class 1) & 2 & 1.2 \\
\hline Middle (class iii) & 19 & 21.4 \\
\hline Upper lower (class iv) & 45 & 56.0 \\
\hline Lower (class v) & 18 & 21.4 \\
\hline Total & 84 & 100.0 \\
\hline
\end{tabular}

Table no 5 depicts distribution of cases on the basis of hospitalisation. Out of 84 alleged dowry victims, $29.8 \%$ female victims are hospitalised and 59 (70.2\%) female victims are brought dead.

Table 5: Hospitalisation among alleged dowry deaths

\begin{tabular}{|c|c|c|}
\hline Hospitalisation & Frequency & Percentage \\
\hline Yes & 25 & 29.8 \\
\hline No & 59 & 70.2 \\
\hline Total & 84 & 100.0 \\
\hline
\end{tabular}

Table no 6 denotes distribution of alleged dowry victims according to the place of incidence. Out of 84 female victims of alleged dowry, in 59 female victims $(70.2 \%)$, the incidence occurred at their own /in-laws residence, while in 25 female victims $29.8 \%$ cases, the incidence occurred at places other than their own residence.

Table 6: Place of incidence among alleged dowry victims

\begin{tabular}{|c|c|c|}
\hline Place of incidence & Frequency & Percentage \\
\hline Own /in-laws house & 59 & 70.2 \\
\hline Other & 25 & 29.8 \\
\hline Total & 84 & 100.0 \\
\hline
\end{tabular}

Table no 7 describes the distribution of percentage of burns injury among alleged dowry deaths and survival period distribution. In maximum burns cases, victims are brought dead $36.36 \%$ and percentage of burns in maximum cases $(50 \%)$ is $71-90 \%$ of Total body surface area.

Table 7: Distribution of percentage of burns acording to survival period

\begin{tabular}{|c|c|c|c|c|c|}
\hline \multicolumn{2}{|c|}{ Percentage of burns 31 TO 50 \% 51 70 } & TO 71 \% 90 & TO >90 TOT \% \% \\
\hline Survival period & Brought 0 dead & $3(37.5)$ & $4(50) 1$ & & $(12.5) 8$ \\
\hline & 0 TO 60 HRS & $1(100)$ & 0 & 0 & 1 \\
\hline & 7 TO 12 0 HRS & $2(33.33)$ & $4(66.66)$ & 0 & 6 \\
\hline
\end{tabular}




\begin{tabular}{|c|c|c|c|c|c|}
\hline & 13 TO 180 HRS & $1(33.33)$ & $2(66.66)$ & 0 & 3 \\
\hline & 19 TO 240 HRS & $1(100)$ & 0 & 0 & 1 \\
\hline & 1 TO 7 1(33.3 DAYS3) & $1(33.33)$ & $1(3(3.33)$ & 0 & 3 \\
\hline Total & 1 & 9 & 11 & 1 & 22 \\
\hline
\end{tabular}

(Figures mentioned in parenthesis are percentages)

Table no 8 shows association of menstruating uterus and suicidal dowry deaths. Out of a total of 35 menstruating female victims, $31(88.57 \%)$ suffered from suicidal deaths and $4(11.42 \%)$ are non- suicidal deaths.

Out of 49 non-menstruating female victims, 33 (67.34\%) suffered non-suicidal deaths, $16(32.66 \%)$ suffered from suicidal deaths.

Table 8: Association of menstruating uterus and suicidal female deaths among alleged dowry deaths

\begin{tabular}{|c|c|c|c|}
\hline Uterus & Non-suicidal & Suicidal deaths & Total \\
\hline Menstruating & $4(11.42)$ & $31(88.57)$ & 35 \\
\hline Non-menstruating & $33(67.34)$ & $16(32.66)$ & 49 \\
\hline
\end{tabular}

(Figures mentioned in parenthesis are percentages)

Table no 9 describes distribution of manner of death according to provocation in alleged dowry deaths. In alleged dowry deaths, our study depicted that along with dowry, other provocative factors also contributed to deaths of married females within 7 years.

Out of 47 suicidal deaths within 7 years of marriage, in 1 $(2.13 \%)$ female victim, the provocative factor for death is love failure/ affair of her husband, 6 (12.77\%) female victims committed suicide due to domestic abuse by the inlaws and $36(76.60 \%)$ female victims committed suicide with dowry as a provocative factor. $2(4.26 \%)$ female victims committed suicide with infertility as a provocative factor and $1(2.13 \%)$ female victim each has RVD and Psychiatric condition like depression is an important provocative factor for suicide.

In maximum suicidal cases within 7 years of marriage, dowry and domestic abuse are important provocative factors and RVD and Psychiatric diseases are least provocative factors for deaths.

Out of 37 homicidal deaths within 7 years of marriage, in 2 $(5.41 \%)$ female deaths, the provocative factor for death is love affair, $9(24.32 \%)$ female victims suffered homicidal deaths due to domestic abuse, $2(5.41 \%)$ female victims suffered homicidal deaths due to economical crisis like when involved in property disputes or high paying insurance policies. In $20(54.05 \%)$ female victims dowry is an important provocative factor for homicidal intent.1 (2.7\%) female victim suffered homicidal death due to unemployment as a provocative factor, wherein the reason for impulsive anger of the accused is the lack of economical input from the female victim to support her family. In 3 $(8.11 \%)$ female victims, the cause of homicidal intent is not known.

In Maximum homicidal deaths within 7 years of marriage, dowry and domestic abuse are major provocative factors, whereas unemployment, love affair and economical crisis are least provocative factors for homicidal intent.

Table 9: Distribution of manner of death according to provocative factors in alleged dowry deaths

\begin{tabular}{|c|c|c|c|c|}
\hline \multicolumn{2}{|c|}{} & \multicolumn{2}{|c|}{ Manner of death } & \multirow{2}{*}{ Total } \\
\cline { 3 - 5 } & Not known & Homicide & Suicide & \\
\hline \multirow{4}{*}{$\begin{array}{c}\text { Provocative } \\
\text { factors }\end{array}$} & Love failure/affair & $2(8.11)$ & 0 & 3 \\
\cline { 2 - 5 } & Domestic abuse & $9(24.32)$ & $6(12.13)$ & 3 \\
\cline { 2 - 5 } & Economic crisis & $2(5.41)$ & 0 & 15 \\
\cline { 2 - 5 } & Dowry & $20(54.05)$ & $36(76.60)$ & 56 \\
\cline { 2 - 5 } & Aids & 0 & $1(2.13)$ & 1 \\
\cline { 2 - 5 } & Psychiatry & 0 & $1(2.13)$ & 1 \\
\cline { 2 - 5 } & Infertility & 0 & $2(4.26)$ & 2 \\
\cline { 2 - 5 } & Unemployment & $1(2.70)$ & 0 & 84 \\
\hline
\end{tabular}

(Figures mentioned in parenthesis are percentages)

Table no 10 shows distribution of marriage years according to provocative factors in alleged dowry deaths. Maximum cases of alleged dowry deaths occurred in 1st year of marriage $(39.29 \%)$. Dowry was a provocative factor in $84.84 \%$ of deaths within first year.

Table 10: Distribution of duration of marriage years according to provocative factors in alleged dowry deaths

\begin{tabular}{|c|c|c|c|c|c|c|c|c|}
\hline Provocative factors & $<\mathbf{1}$ & $\mathbf{1}$ to $\mathbf{2}$ & $\mathbf{2}$ to 3 & $\mathbf{3}$ to 4 & $\mathbf{4}$ to 5 & $\mathbf{5}$ to 6 & $\mathbf{6}$ to 7 & Total \\
\hline Not known & $1(3.03)$ & $1(5)$ & $1(7.14)$ & 0 & 0 & 0 & 0 & 3 \\
\hline Love failure/affairs & 0 & $1(5)$ & 0 & 0 & $2(33.33)$ & 0 & 0 & 3 \\
\hline Domestic abuse & $4(12.12)$ & $2(10)$ & $5(35.71)$ & 0 & $1(16.67)$ & $2(40)$ & $1(50)$ & 15 \\
\hline Economic crisis & 0 & $1(5)$ & 0 & 0 & $1(16.67)$ & 0 & 0 & 2 \\
\hline Dowry & $28(84.84)$ & $15(75)$ & $6(42.86)$ & $2(50)$ & $1(16.67)$ & $3(60)$ & $1(50)$ & 56 \\
\hline Aids & 0 & 0 & 0 & $1(25)$ & 0 & 0 & 0 & 1 \\
\hline Psychiatry & 0 & 0 & $1(7.14)$ & 0 & 0 & 0 & 0 & 1 \\
\hline Infertility & 0 & 0 & 0 & $1(25)$ & $1(16.67)$ & 0 & 0 & 2 \\
\hline Unemployment & 0 & 0 & $1(7.14)$ & 0 & 0 & 0 & 0 & 1 \\
\hline Total & $33(39.29)$ & $20(23.8)$ & $14(16.67)$ & $4(4.76)$ & $6(7.14)$ & $5(5.95)$ & $2(2.38)$ & 84 \\
\hline
\end{tabular}

(Figures mentioned in parenthesis are percentages) 


\section{Discussion}

Out of 84 female victims of alleged dowry death, maximum alleged female dowry victims were from the age group of 21 to 30 years of age and minimum were from the age group of 41 to 50 years of age.

Similar findings were noted in a study of Rajesh Kumar Verma et al. ${ }^{[4]}$, where in, maximum number of deaths $(56.56 \%)$ occurred between $18-25$ years of age and least $(5.43 \%)$ in the age-group 31-35 years.

Following studies gave similar results- Shrivastava ${ }^{[5]}$ AK et al., Kulshreshta ${ }^{[6]} \mathrm{P}$ et al., Sharma ${ }^{[7]} \mathrm{BR}$ et al., Harish D et al. ${ }^{[8]}$, Ghaffar UB ${ }^{[9]}$ et al., Kumar $\mathrm{V}^{[10]}$, et al., Saha KK ${ }^{[11]}$ et al. and Agnihotri A et al. 166.

The high incidence of unnatural deaths in young emotionally charged females is most probably due to unending demands of dowry (cash/ kinds) by their husbands and/or in-laws, for which they sometimes kill or torture the bride in such a way that she commits suicide, which is consistent with other authors findings.

And brides belonging to the age group of 41 to 50 years are those who committed a late marriage, which is noted mostly among educated independent working females and hence, the incidence of allegedly dowry deaths is comparatively less. This being a comparatively emotionally mature age group, alleged dowry deaths are comparatively less.

Maximum number of female victims of alleged dowry were housewives (77.4\%) which may be attributed to financial dependency of housewives and minimum number of professionals $(2.4 \%)$ with 1 victim who was working as house help.

Similar findings were noted in Prajapati $\mathrm{P}$ et al. ${ }^{[13]}$ and Kumar T N S ${ }^{[14]}$ et al. Studies.

Maximum female victims were illiterate (39.3\%). Only $(3.6 \%)$ female victims are Professionals and $(2.4 \%)$ received intermediate school education, which results in maximum dependant female population leading to exploitation and abuse of these females. In Saha et al. ${ }^{[11]}$ and Kumar V et al. ${ }^{[15]}$, wherein maximum female dowry victims are illiterate and minimum female victims are professionals similar to present study.

Maximum female victims of alleged dowry death belonged to upper lower socioeconomic class $(56 \%)$ and minimum belonged to upper socio-economic class $(21.4 \%)$. Dowry is considered as an evil of lower socio-economic group due to illiteracy and ignorance.

Sharma BR, et al. ${ }^{[7]}$ and Kumar V et al. ${ }^{[15]}$ states similar results.

Out of 84 alleged dowry victims, $29.8 \%$ female victims are hospitalised and $59(70.2 \%)$ female victims are brought dead. Dowry victims in most cases are deprived from hospital services which may be because of ignorance of their relatives to hospitalise the victims.

Out of 84 female victims of alleged dowry, in 59 female victims $(70.2 \%)$, the incidence occurred at their own residence, while in 25 female victims $29.8 \%$ cases, the incidence occurred at places other than their own residence. Similar findings are noted by Dasari et al.

${ }^{[16]}$ Sixty one percent females (105) suffered burns in their in-laws house while the rest at other places.

Similar findings were noted by Jaswinder Singh ${ }^{[17]}$ et al., wherein $67.34 \%$ incidences occurred in in-laws house, while remaining occurred in other places.

In maximum burns cases, victims are brought dead $36.36 \%$ and percentage of burns in maximum cases $(50 \%)$ is 71 $90 \%$ of Total body surface area. With increasing percentage of body surface area involved in burns injury, the fatality rate increases.
Simillar to Sharma BR ${ }^{[16]}$ and Modi JP ${ }^{[17]}$ also states that death in burns injury may occur within $24-48$ hours, but the first week is most fatal.

Out of a total of 35 menstruating female victims, 31(88.57 $\%)$ suffered from suicidal deaths and $4(11.42 \%)$ are nonsuicidal deaths.

Out of 49 non-menstruating female victims, 33(67.34\%) suffered non-suicidal deaths, $16(32.66 \%)$ suffered from suicidal deaths.

Strong association between menstruating uterus and suicidal deaths is observed.

The first (or menstrual) and fourth (or premenstrual) week of the menstrual cycle may be associated with many suicide attempts in women, stated by Baca-Garcia ${ }^{[18]}$ et al.

Out of 47 suicidal deaths within 7 years of marriage, in 1 $(2.13 \%)$ female victim, the provocative factor for death is love failure/ affair of He husband, 6 (12.77 \%) female victims

committed suicide due to domestic abuse by the in-laws and $36(76.60 \%)$ female victims committed suicide with dowry as a provocative factor. $2(4.26 \%)$ female victims committed suicide with infertility as a provocative factor and $1(2.13 \%)$ female victim each has RVD and Psychiatric condition like depression is an important provocative factor for suicide.

In maximum suicidal cases within 7 years of marriage, dowry and domestic abuse were important provocative factors and RVD and Psychiatric diseases are least provocative factors for deaths.

Out of 37 homicidal deaths within 7 years of marriage, in 2 $(5.41 \%)$ female deaths, the provocative factor for death is love affair, $9(24.32 \%)$ female victims suffered homicidal deaths due to domestic abuse, 2(5.41\%) female victims suffered homicidal deaths due to economical crisis like when involved in property disputes or high paying insurance policies. In $20(54.05 \%)$ female victims dowry is an important provocative factor for homicidal intent. 1 (2.7\%) female victim suffered homicidal death due to unemployment as a provocative factor, wherein the reason for impulsive anger of the accused is the lack of economical input from the female victim to support her family. In 3 $(8.11 \%)$ female victims, the cause of homicidal intent was not known.

In Maximum homicidal deaths within 7 years of marriage, dowry and domestic abuse are major provocative factors, whereas unemployment, love affair and economical crisis are least provocative factors for homicidal intent.

Similar to Biswadeep Paul et al. ${ }^{[19]}$, family disputes pertaining to Dowry deaths including failure in love accounted for highest number of burns injury deaths. In 2010, according to NCRB, a total of 8391 and in 2016, 8618 dowry deaths are reported in India, while in Assam according to Crime Statistics, 121 female deaths are observed and according to National Crime Bureau, a dowry death occurs every 77 minutes.

Similar to the findings of Guntheti et al. ${ }^{[20]}$, where in dowry and harassment from in-laws are important provocative factors. Similar findings were noted in Dere Rajesh ${ }^{[21]}$ et al. and Meera $\mathrm{T}^{[22]}$ et al.

According to T.C. Siddaramanna ${ }^{[23]}$ et al., family issues are important cause of poisoning and Chakrabarthy ${ }^{[24]}$ et al., more than one-third of deaths due to domestic conflict, marital disharmony, quarrel.

Another study with similar findings is Shrivastav ${ }^{[5]}$ et al., with dowry $(25 \%)$ and domestic abuse $(26.39 \%)$ being an important provocative factor for suicidal deaths and infertility $(4.17 \%)$ and poverty $(5.56 \%)$ being the 
provocative factors for least suicidal deaths among newly married females.

Maximum cases of alleged dowry deaths occurred in 1st year of marriage $(39.29 \%)$ with dowry as an important provocating factor in $84.84 \%$ of deaths in 1 st year of marriage.

Dowry and domestic abuse were important provocative factors for death after marriage within 7 years in alleged dowry victims. Dowry was an important factor for death within first three years of marriage. While infertility is an important provocative factor in the 3rd and 4th decade of married life, when the family pressure for bearing a child increases and hence, is a trigger factor for suspicious death. This relationship of provocative factors and duration of marriage years was studied uniquely in this study.

\section{Conclusions}

Incidence of dowry deaths among unnatural deaths is 34.85 $\%$ which is higher considering the fact that the study is conducted within city. Maximum cases of alleged female dowry deaths were from younger and reproductive group which is emotionally labile. Maximum housewives, illiterate belonging to upper lower socioeconomic class suffered death.

Maximum deaths occurred within first year of marriage and did not receive hospitalisation services. Dowry was an important provocative factor in most of the deaths along with domestic abuse and infertility. Most of the deaths occurred at their own or in-laws residence. Most of the alleged cases of dowry were suicidal and most of the suicides were during the menstruation phase of cycle. Asphyxia was the cause of death in most cases and a significant number of Burns injury cases were also noted.

\section{Acknowledgements}

Sincere regards to all the teaching and non-teaching staff of Department of Forensic Medicine and Toxicology, Grant Government Medical College and Sir J.J. Group of Hospital for their moral support and guidance.

\section{References}

1. Mangoli RN, Tarase GM. Crime against woman in India.A Statistical review. International Journal of Criminology and Sociology theory. 2009; 2(2):292-302.

2. Park K. Park's Textbook of Preventive and Social Medicine, Jabalpur; 21st ed. M/s Banarsidas Bhanot Publishers, 2011, 525, 645.

3. Crime in India. Compendium. New Delhi: Government of India, Minister of Home Affairs, National Crime Record Bureau Report 59th Edition. 2011-2012; 28:190.

4. Datta Damayanti (4 December 2006). The new laws of marriage. India Today. Retrieved 29 March, 2013.

5. Shrivastava AK, Arora P. Suspicious Deaths in Newly Married Females-A Medicolegal Analysis. Journal of Indian Academy Forensic Medicine. 2007; 29(4):6367.

6. Kulshreshtha P, Sharma RK, Dogra TD. Study of Sociological and demographical variables of unnatural deaths among young women in south Delhi within seven years of marriage. Journal of Punjab Academy of Forensic Medicine and Toxicology. 2002; 2:7-17.

7. Sharma BR, Singh VP, Sharma R, Sumedha. Unnatural Deaths in Northern India-A Profile. Journal Indian Academy Forensic Medicine. 2004; 26(4):140-146.
8. Sharma BR, Harish D, Sharma A, Sharma, Singh H. Accidental burns in Indian kitchen; Are they really accidents? JIAFM. 2006; 28(1):14-17.

9. Ghaffar UB, Hussain M, Rizvi SJ. Thermal Burn: An Epidemiological Prospective Study. Journal of Indian Academy Forensic Medicine. 2008; 30(1):10-14.

10. Koulapur VV, Yoganarsimha K, Gouda H, Mugadlimath A, Kumar VAG. Analysis of Fatal Burns Cases-A 5 Year study At Sri B M Patil Medical College, Bijapur, Karnataka Medico-Legal Update. 2011; 11(2):107-109.

11. Saha KK, Mohanty S. Alleged Dowry Death: A study of homicidal burns. Med. Sci. Law. 2006; 46(2):105.

12. Agnihotri A. The Epidemiological Study of Dowry Death Cases with Special references to burn cases in Allahabad zone. Anil Aggarwal S Internet Journal of F.M \& T. 2001; 2(1):201-205.

13. Prajapati P, Shaikh MI, Patil R. Bride Burning; A Heinous Crime. Journal of Indian Academy of Forensic Medicine. 2011; 33(1):90-92.

14. Kumar TNS, Mahathi K, Thirthala S. Role of Constitution in Women Empowerment in Corporate Sector. Arabian J Bus Manag Review. 2016; 6:267.

15. Kumar V, Tripathi CB, Kanth S. Burn Wives - A Sociologic Study. International Journal of Medical Toxicology \& Legal Medicine. 1999; 2(1):18.

16. Sharma BR, Harish D, Sharma V, Vij K. Burns. Kitchen accidents vis-a-vis dowry deaths. 2002; 28(3):250-253.

17. Modi JP. Textbook of Medical Jurisprudence and Toxicology. 25th ed. Lexis Nexis, 2016, 159-162.

18. Enrique Baca-Garcia, Carmen Diaz-Sastre, Antonio Ceverino, Mercedes Perez- Rodriguez M, Rocio Navarro-Jimenez, Jorge Lopez-Castroman, JeronimoSaiz-Ruiz, Jose de Leon and Maria A. Oquendo, Suicide attempts among women during low estradiol/low progesterone states, Journal of Psychiatric Research. 2010; 44(4):(209).

19. Biswadeep Paul, Putul Mahanta, Raktim Pratim. Tamuli. A Statistical Ananlysus of Death Victims brought for Medico-legal Autopsy. Medico-legal Update. 2013; 13(2):98-101.

20. Guntheti BK, Singh UP. The pattern of Poisoning in Khammam. Journal of Indian Academy of Forensic Medicine. 2011; 33(4):296-300.

21. Dere RC, Col Rajoo KM. Study of Unnatural Deaths in Females A Medicolegal Study at Rural Medical College, Loni. Journal of Indian Academy of Forensic Medicine. 2011; 33(3):211-213.

22. MeeraTh, Singh MBK. Pattern of neck findings in suicidal hanging a study in Manipur. Journal of Indian Academy of Forensic Medicine. 2011; 33(4):352-354.

23. Siddaramana TC, Dileep Kumar R, Rudramurthy S. Deaths due to Orgnophosphorus Poisoning-A Retrospective Study, J Indian Acad Forensic ed. JulySeptember. 2016; 38(3):278-279.

24. Chakrabarthy P, Tudu NK, Saren AB, Dwari AK, Haldar D, Samanta S. Epidemiology of unnatural death from suspected poisoning: an autopsy based study. IOSR-Journal of Dental and Medical Sciences, 2015, 18. 